\title{
Human Resources Management Effectiveness for Client Satisfactions and Bank Reputations (Case of State-owned Banks in Indonesia)
}

\section{Suhartono ${ }^{1}$ and Kartini Istikomah ${ }^{2}$}

${ }^{1}$ Postgraduate Programs, Universitas Budi Luhur, Jakarta, Indonesia

${ }^{2}$ Faculty of Economics and Business, Universitas Budi Luhur, Jakarta Indonesia

\section{Abstract}

The aim of this study is to explore the role of human resources management (HRM) practices in sustaining banks' competitiveness and reputations. It was to ascertain the effectiveness of the HRM policies to enhance the service quality, employee credibility, corporate communications, those all simultaneously for higher client satisfaction and greater reputation of the banks. The exploration was intended for bank assessment prior a merger scheme of four state-owned banks into a one-state

Corresponding Author:

Suhartono

suhartono@budiluhur.ac.id

Received: 29 August 2018

Accepted: 18 September 2018

Published: 11 November 2018

Publishing services provided by Knowledge $\mathrm{E}$

(c) Suhartono and Kartini Istikomah. This article is distributed under the terms of the Creative Commons

Attribution License, which permits unrestricted use and redistribution provided that the original author and source are credited.

Selection and Peer-review under the responsibility of the ICOI-2018 Conference Committee.

\section{G OPEN ACCESS}

holding bank. The respondent for the study was the bank clients with at least 10 years of loyalty. Survey by google form questionnaires, being emailed during February-April 2017. Sample chosen by purposive random sampling. The questionnaires' return rate was $42 \%$ of 420 google forms sent. The analysis was applying the Structural Equation Modelling (SEM), examining the goodness of fit for the structural model and the data. Examination was also done for measurement model of every single construct. The study revealed that bank reputation significantly correlated to service quality, employee credibility, and client satisfactions, but less related to corporate communications. Discussion and implication of these findings were deliberated with detail in the article.

Keywords: service quality, employee credibility, corporate communication, client satisfaction, bank reputation

\section{Introduction}

The issues of a one holding bank of the state owned banks (SOB) are still on going up until now. Merger of four banks, that is, Bank Mandiri, Bank Negara Indonesia (BNI), Bank Rakyat Indonesia (BRI) and Bank Tabungan Negara (BTN) was the central issues, recently. The merger would be the advantage for Indonesian banking businesses, since it would potentially be improving its rank within the region; it would be uprising it at the top four rank of banks in South East Asia (ASEAN), in term of the asset worth [38]. All banks in the country have been consistently and persistently work on 
refining every single aspect of the human resources management (HRM) policies; the Indonesia financial services authority (FSA) or Otoritas Jasa Keuangan (OJK) was signaling on continual scrutinizing all the banks for the policies [24]. Banks currently have been exercising HRM policies with various works and programs. Strong healthy bank does run the business with thoughtful commitment for the policies. Individual banks typically apply utterly the HRM policies in training and development, risk management, quality services and corporate communications; all in according with the central bank regulation number 13/27/PBI/2011 [3].

In domestic market SOBs have a number of advantages. Theis (2016) contended that the financial performance of SOBs were better than private banks. Most of banks reputation were represented by the number of ATM (automated teller machines) they own, the quality of internet banking and the phone-banking [22, 29, 34]. Unlikely, the quality of internet banking between SOB and private banks in Indonesia were in fact equal in its level of services [23]. Whilst the growth rate of profit for private banks were indicated better than the SOBs [4]. Based on those phenomenon the study would to ascertain the effectiveness of the existed HRM policies for possible capabilities for sustaining the SOBs competitiveness and reputations.

\section{Literature Review}

Researchers in HRM have dedicated substantial energies toward validating that managing people, especially through HR practices, have strong linkage with performance $[10,13,22,40]$. Unfortunately there is no fixed list of HR practices or systems of practices that are used to define or measure human resource management [27]. Hence, HRM policies or HRM system of practices are defined as continuing guidelines on the approach the organization intends to adopt in managing its people, as all also is confirmed by Berman (2016)

Boselie, P., Dietz, G., Boon, (2005) and Boselie, (2010) identify 26 different practices that are used in different 104 studies; the top four, in order of acceptance, are training and development, contingent pay and reward schemes, performance management (including appraisal), and careful recruitment and selection. This study assumed that HRM policies are about corporation schemes intended for individuals and team advancements with particular principles in governing, with technical guidance in how, when, by whom for vital identifiable duties with explicit measurable goals.

Hence, the study applied Savaneviciene \& Stankeviciute, (2010) and Savaneviciene \& Stankeviciute, (2012) Model of the expectancy theory of motivation provides one 
possible basis for developing a more coherent rationale about HRM-Performance link. The theory proposes that performance at individual level depends on high motivation, possession of the necessary skills and abilities, and an appropriate role and understanding of that role (Vroom 1964; Porter and Lowler III, 1968). Only these HRM practices impact HRM outcomes, as Becker and Gerhart (1996), Becker and Huselid (1998) listed that HRM practices influence behavior outcomes, which translate into performance outcomes, which result in financial outcomes.

Guest, (1997) and Guest, D. E., Michie, J., Conway, N., and Sheehan, M., (2003) described all the cause and effect relations as follows: HRM strategy (i.e., differentiation, focus, cost) $\rightarrow$ HRM practices (i.e., selection, training, appraisal, rewards, job design, involvement, status and security) $\rightarrow$ HRM outcomes (i.e., commitment, quality, flexibility) $\rightarrow$ Behavior outcomes (i.e., effort and motivation, cooperation, involvement, organizational citizenship) $\rightarrow$ Performance outcomes (i.e., high productivity, quality, innovation; low absence, turnover, conflict, customer complaints) $\rightarrow$ Financial outcomes (i.e., profits, ROI). Additionally, the study extended the formula with the impact on corporate reputation and exchange part of the HRM practices with corporate communications which frequently it is the HRM duties. HR managers could focus on initiatives that build employee competencies that add value to important organizational outcome, including corporate reputation. In addition HR functions should implement initiatives that increase employee's motivations to drive corporate reputation when interacting with external stakeholder including and particularly for customers satisfactions [18].

Riel, C. B. M., (2007) defined that the third type of communications is organizational communications, all covering: public relations, public affairs, investor relations, corporate advertising, and internal or employee communications. Corporate communication aims at cooperate audiences, such as clients, shareholders, financial journalist, investment analysts, regulators, and legislators. Organizational communications have a longterm perspective and do not directly aim at generating sales. Most communications apply with diverse style of communications compared to marketing communications. External pressures force the corporation to disclose the information; as Dozier, (1992); Dozier, D.M., Grunig, L.A., Grunig, J.E., (1995) points out that corporations should communicate wisely with those external audiences for particularly commercial aspects.

Lehtinen, J.R., Lehtinen, (1982) articulated that service quality hold that it is a perceived gap judgement the customer makes between his expectations and perception about the way services delivered. While several authors have emphasized the multidimensional nature of service quality $[19,26,28,31]$, the majority of research 
pertaining to service quality has focused on the measurement of service quality based on the functional dimension, and less focus on technical dimension. Hence, mostly all define that quality services materialized only if the employees have integrity and competences, those all about the employee credibility.

The study of Kotler, P., Adam S., Denize, S., Armstrong, G., (2008), Dees, J. G., Anderson, (2006), and Anderson J.W, Sullivan, (1993) suggest that customer satisfaction is the main factor in developing reputation and credibility. It supports customer-oriented marketing and finds that satisfaction of customers with products and services is of fundamental importance in building a reputable and credible image of an organization.

Topalian (1984) hypothesized that corporate reputation refers to the expectation, attitudes and feeling that customers have about the very nature of the corporate activities and communications. Dowling, (1986) defined that a reputation is the set of meaning by which a company is known and through which people describe, remember an relate to it. It is net result of the interaction of a person's beliefs, ideas, felling and impression about the company. A company will not have the reputation, but society at large hold the reputation of the company. Alvesson, (1990) postulated that reputation refers to holistic and vivid impression held by a particular group of constituents toward a company, it partly the result of sense-making held by the group members about corporation actions and communications. Fombrun, (1996) posited that reputation could harm the organization's image since corporate reputations are the overall expectations held by its constituents.

Based on recent Indonesian banking phenomenon and the literatures reviewed earlier, the study first outlined the aforementioned research paradigm (Figure 1). It is the research paradigm of HRM effectiveness for sustaining banking competitiveness and reputations. It portrays the rational of five constructs, that is, Service Quality (SQ), Employee Credibility (EC), Corporate Communications (CC), Clients Satisfaction (CS) and Bank Reputation (BR), while all of each include the measurable factors.

The study generated nine hypothesis, all related to the extension of the goodness of fit test for the structural modelling outlined in Figure 1.

Hypothesis 1: A direct relations and significant effect of service quality for client satisfaction.

Hypothesis 2: A direct relations and significant effect of employee credibility for client satisfaction

Hypothesis 3: A direct relations and significant effect of corporate communication for client satisfaction. 


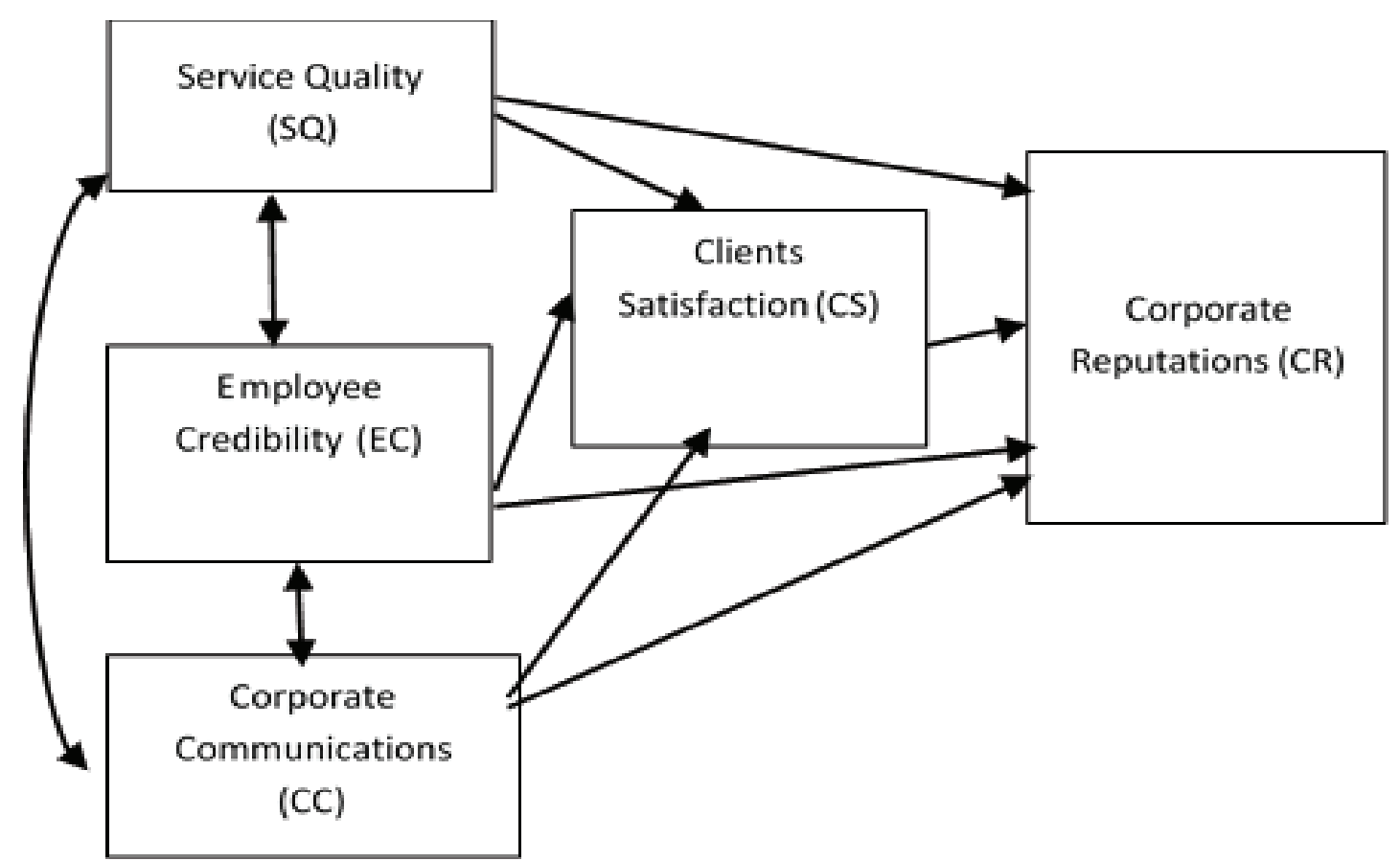

Figure 1: Research Paradigm of HRM effectiveness for sustaining banks competitiveness and reputations.

Hypothesis 4: A direct relations and significant effect of service quality for corporate reputation.

Hypothesis 5: A direct relations and significant effect of employee credibility for corporate reputation.

Hypothesis 6:A direct relations and significant effect of corporate communication for corporate reputation.

Hypothesis 7: An indirect relations and significant effect of service quality for corporate reputation though the client satisfactions.

Hypothesis 8: An indirect relations and significant effect of employee credibility for corporate reputation through the client satisfaction.

Hypothesis 9: An indirect relations and significant effect of corporate communications for corporate reputation through the client satisfaction.

\section{Methods}

The respondent for the study was the bank clients with at least 10 years long of loyalty. The banks were Bank Mandiri, Bank Negara Indonesia (BNI), Bank Rakyat Indonesia (BRI) and Bank Tabungan Negara (BTN). Survey were by questionnaires in 
google form design. All being emailed by the authorities of the banks during February - April 2017. Sampling chosen by purposive random sampling for retail and individual clients. The questionnaire return rate was $42 \%$ out of the total of 420 google forms sent. The analysis was working on the Structural Equation Modelling (SEM) with AMOS application.

\section{Results and Discussion}

All Standardized Loading Factors for all indicators in each construct were $>0.50$, except one indicator of employee credibility (i.e., EC 6 was $0.402<0.50$ ); it had therefore been excluded for the goodness of fit test. The results based on SEM statistical analysis and data depicted as follows, basically concluded that the structural model and the measurement model used in the study were sufficient. Numeral indicators for GFI = $0.828>0.80 ; \mathrm{CFI}=0.906>0.900 ;$ and NNFI $=0.895>0.80$, all indicated that the structural modelling of the study was satisfy the goodness of fit test. Moreover the RMSEA was $0.059<0.089$ indicated that most the constructs used in the study and the relational amongst them were correct [9].

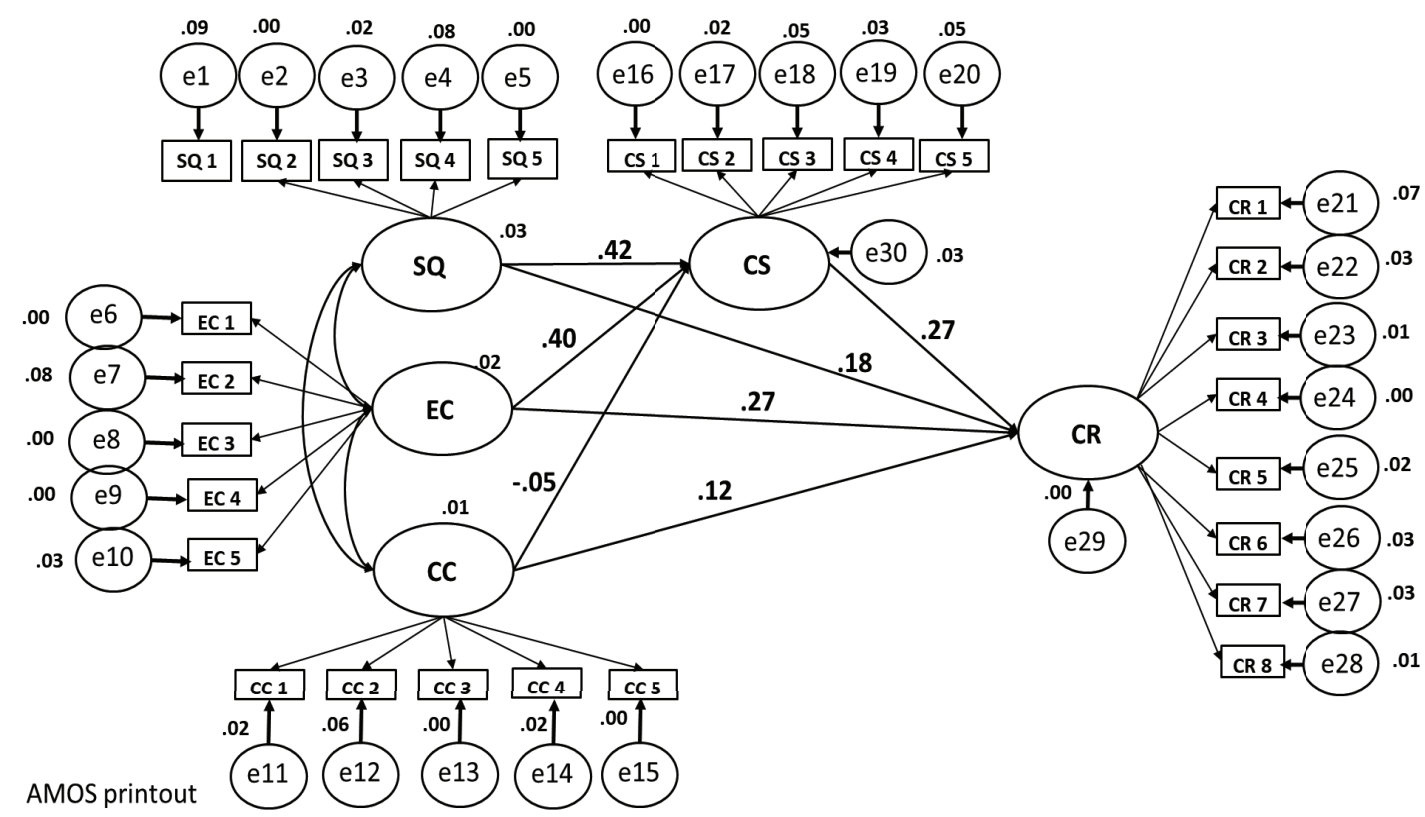

Figure 2: Full structural model of HRM effectiveness for sustaining banks competitiveness and reputations.

The research work also demonstrated that the bank reputations were correlated with and significantly affected by the service quality, the employee credibility and the customer satisfaction, but not particularly by corporate communications. The latter was a unique phenomenon of the finding of the study. It was an anomaly and the antithesis 
reversing the previous studies, about the corporate communications being related to and significantly affected the reputations $[5,11,35]$.

Based on the list of Estimated Partial Path Coefficient Regression (Table 1), also by applying the Wright. S, (1960) formula, the analysis would define the total path coefficient regression $(\beta)$ of direct and indirect correlation for the exogenous constructs with the endogenous construct. In this study, all defined for the best prediction of the role of each exogenous construct for the corporate reputations.

First, the total path coefficient regression $(\beta)$ for direct and indirect correlation between corporate communication and corporate reputation could be totaled as: $0.118+(-0.048 * 0.267)=0.105$ (Hypotheses 3, 6 and 9). It estimated that corporate communication directly and indirectly was supporting $10.5 \%$ of the existed corporate reputation. Second, with the same token, $\beta$ for the construct of service quality could be calculated as: $0.184+(0.416 * 0.267)=0.295$. It was estimated that service quality directly and indirectly was supporting $29.5 \%$ of the existed corporate reputation (Hypotheses 1, 4 and 7). Additionally, $\beta$ for the construct of employee credibility could be counted as follow: $0.265+(0.406 * 0.267)=0.373$. It was estimated that employee credibility directly and indirectly was supporting $37.3 \%$ of the existed corporate reputation (Hypotheses 2, 5, and 8).

TABLE 1: Estimated Partial Path Coefficient Regression.

\begin{tabular}{l|c|c|c|c|}
\hline Variable & Estimation & $\mathrm{S}, \mathrm{E}$ & $\mathrm{C} . \mathrm{R}$ & $\mathrm{P}$ \\
\hline $\mathrm{CS} \leftarrow \mathrm{SQ}$ & 0.416 & 0.131 & 3.176 & 0.001 \\
\hline $\mathrm{CS} \leftarrow \mathrm{EC}$ & 0.404 & 0.134 & 3.039 & 0.002 \\
\hline $\mathrm{CS} \leftarrow \mathrm{CC}$ & -0.048 & 0.099 & -0.448 & 0.626 \\
\hline $\mathrm{CR} \leftarrow \mathrm{CS}$ & 0.267 & 0.112 & 2.385 & 0.017 \\
\hline $\mathrm{CR} \leftarrow \mathrm{SQ}$ & 0.184 & 0.087 & 2.126 & 0.034 \\
\hline $\mathrm{CR} \leftarrow \mathrm{CC}$ & 0.118 & 0.056 & 2.094 & 0.036 \\
\hline $\mathrm{CR} \leftarrow \mathrm{EC}$ & 0.265 & 0.088 & 3.005 & 0.003
\end{tabular}

All implicitly told us that the bank communications were not the key issues in effecting the higher customer satisfaction, thus it was also not the key issues in effecting the greater bank reputation. The statistical finding for the study was indicating that corporate communication was harmfully effecting the clients satisfaction, yet insignificantly; also prompted it the reputation at the lowest impact ( $\rho=0.626>0.05$ and $\beta$ $=-0.048)$. All suggested that bank communications were not the key issues for the customer satisfactions, nor the greater bank reputations as well.

Demographic data for the respondents were uncovering distinctive and exclusive information, primarily for deeper analysis of anomaly noticed earlier. The data of ages 
for the respondents were evidently at the average of 49.2 year old, with round 17.3 year longevity of trustworthiness on a bank, and mostly (72\%) they have only one bank account. Largerly $(72 \%)$ of the repondents were employees and the rest $(28 \%)$ were the owners or the decision-makers of a firm. Typically they had been at the current position for 6 years. Their average monthly saving was around IDR 3 to 11 million. The average banking transactions were monthly IDR 15 to 30 million; about $52 \%$ of the transactions being with the conventional banking services and the ATM (automated teller machine).

All the aforementioned specified that the SOB's clients were at the end of their midcareer-level with higher level fanatism to a bank. They were loyalist and were confortably running the business with existing conventional banking transactions. Their trust level for the bank were quite high. It validated the reason on why the bank communication were not significantly provoking client satisfactions; it consequently was correspondingly not stimulating the bank reputations. These suppositions also supported by statistical data for the construct of corporate communication; the construct reliability was only.65, at the lowest level of other constructs (see Table 2). Statistically it justified that the corporate communications were not the salient construct for the model; meaning that the corporate communications were not the interest of the existed clients, since they preserved higher level of trust on the existing bank.

TABLE 2: Construct Reliability List.

Construct
Service Quality
Employee Credibility
Corporate Communications
Client Satisfaction
Corporate Reputation

\begin{tabular}{|c|}
\hline Construct Reliability \\
\hline 0.83 \\
\hline 0.82 \\
\hline 0.65 \\
\hline 0.80 \\
\hline 0.87 \\
\hline
\end{tabular}

\begin{tabular}{|c|}
\hline Remarks \\
\hline Good \\
Good \\
\hline Reasonable \\
\hline Good \\
\hline Good
\end{tabular}

\section{Conclusion}

1. HRM effectiveness for higher quality services, higher employee credibility and better corporate communications would certainly influence higher client satisfactions, also directly and indirectly creates greater bank reputations.

2. Best roles in enhancing greater bank reputation was derived from HRM practices for higher employee credibility (37.3\%), HRM practices for higher quality services (29.5\%) and lastly HRM practice for better corporate communications (10.5\%). 
All would be creating higher client satisfaction and greater corporate reputation, except practices for undue better corporate communications.

3. The existing clients could not evidently fully support the bank on working for greater corporate reputation, since they are mostly the X Generations. They are at the very modest in progressing and being passive in seeking for their own prospects, except they are enjoy the challenge for the technology advancement [37]; they are however, the loyal and honest persons.

Implications of the finding: there are three salient issues to address the realization of Indonesian SOB Holding:

1. The existing SOBs supposed to expand the market into younger $Y$ or Millennial Generations and creating closed partnership with them to work on contemporary banking and financing services with advanced technology banking systems.

2. Maintain and educate consistently and continually the existing clients the X Generations with rewards for advance banking and financing techniques.

3. Prepare for selecting and hiring the Board of Directors for the holding, the author suggests particularly for a team consisting of the ones who the former executives of the prior merger banks, by additional (plus) the executives of the BTPN (Bank Tabungan Pensiunan Negara). The rationale for the latter was that the bank possessed full abundant experience in assisting investors and customers with high risk aversion attitudes, while it was relatively a new SOB with about par achievements alongside the rivalry.

\section{References}

[1] Alvesson, M. (1990). Organization: From substance to image? Organization Studies, vol. 11, pp. 373-394.

[2] Anderson, J. W. and Sullivan, M. W. (1993). The antecedents and consequences of customer satisfaction for firms. Marketing Science, vol. 12, no. 2, pp. 125-143.

[3] Bank Indonesia. (2015). Perkembangan Perbankan Indonesia tahun 2010-2015. Laporan Tahunan Perbankan.

[4] Bank Indonesia. (2016). Mengoptimalkan Potensi, Memperkuat Resiliensi.

[5] Barnett, M., Jermier, J., and Lafferty, B. (2006). Corporate reputation: The definitional landscape. Corporate Reputation Review, vol. 9, no. 1, pp. 26-38. 
[6] Berman, S. (2016). Why human resources policies and practices are critical to improving the patient experience. Patient Experience Journal, vol. 3, no. 2, article 3.

[7] Boselie, P., Dietz, G., and Boon, C. (2005). Commonalities and contradictions in HRM and performance research. Human Resource Management Journal, vol. 15, no. 3, pp. 67-94.

[8] Boselie, P. (2010). High performance work practices in the health care sector: A Dutch case study. International Journal of Manpower, vol. 31, no. 1, pp. 42-58.

[9] Browne, M. W. and Cudeck, R. (1993). Alternative ways of assessing model fit, in K. A. Bollen and J. S. Long (eds.) Testing Structural Equation Models, pp. 136-162. New-bury Park, CA: SAGE Publishing.

[10] Buoziute-Rafanaviciene, S., Pundziene, A., and Turauskas, L. (2009). Relation between the attributes of executive successor and organizational performance. Engineering Economics, vol. 62, no. 2, pp. 65-74.

[11] Chun, R. (2005). Corporate reputation: Meaning and measurement. International Journal of Management Reviews, vol. 7, no. 2, pp. 91-109.

[12] Dees, J. G. and Anderson, B. B. (2006). Framing a theory of social entrepreneurship: Building on two schools of practice and thought, in R. Mosher-Williams (ed.) Research on Social Entrepreneurship: Understanding and Contributing to an ARNOVA Occasional Paper Series, pp. Emerging Field, vol. 1, no. 3, pp. 39-36.

[13] Delery, J. E. and Doty, D. H. (1996). Modes of theorizing in strategic human resource management: Tests of universalistic, contingency, and configurations. Performance predictions. Academy of Management Journal, vol. 39, no. 4, pp. 802-835. Retrieved from https://doi.org/10.2307/256713

[14] Dowling, G. R. (1986). Managing corporate images. Industrial Marketing Management, vol. 15, pp. 109-115.

[15] Dozier, D. M., Grunig, L. A., and Grunig, J. E. (1995). Manager's guide to excellence in public relations and communication management, in Excellence in Public Relations and Communication Management, pp. 327-355. Mahwah, NJ: Hillsdale NJ: Lawrence Erlbaum.

[16] Dozier, D. M. (1992). The organizational roles of communications and public relations practitioners, in J. Grunig (ed.) Excellence in Public Relations and Communication Management. Hillsdale, NJ: Lawrence Erlbaum.

[17] Fombrun, C. (1996). Reputation: Realizing Value from the Corporate Image. Boston, MA: Harvard Business School Press. 
[18] Friedman, B. A. (2009). Human resources management role implication for corporate reputation. Corporate Reputation Review, Palgrave Macmillan, vol. 12, no. 3, pp. 229-244.

[19] Gronroos, C. (1982). Strategic management and marketing in service sector. Cambridge, MA.: Marketing Science Institute.

[20] Guest, D. E., Michie, J., Conway, N., et al. (2003). Human resource management and corporate performance in the UK. British Journal of Industrial Relations, vol. 41, no. 2, pp. 291-314.

[21] Guest, D. E. (1997). Human resource management and performance: A review and research agenda. The International Journal of Human Resource Management, vol. 8, no. 3, pp. 263-276.

[22] Hamid, J. (2013). Strategic human resource management and performance邓: The universalistic approach - Case of Tunisia. Journal of Business Studies Quarterly, vol. 5, no. 2, p. 184.

[23] Hermana, B. and Silfianti, W. (2011). Evaluating e-government implementation by local government: Digital divide in internet based public services in Indonesia. International Journal of Business and Social, vol. 2, no. 3, pp. 156-164.

[24] Komisioner, D. and Jasa, 0. (2017). No Title.

[25] Kotler, P., Adam S., Denize, S., et al. (2008). Principles of Marketing (fourth edition). Frenchs Forest NSW: Pearson Education Australia.

[26] Lehtinen, J. R. and Lehtinen, U. (1982). Service Quality: A Study of Quality Dimensions. Helsinki.

[27] Paauwe, J. and Boselie, P. (2005). HRM and performance: What next? Human Resource Management Journal, vol. 15, no. 4, pp. 68-83. Retrieved from https: //doi.org/10.1111/j.1748-8583.2005.tboo296.x

[28] Parasuraman, A., Zeithaml, V. A., and B. L. L. (1988). SERVQUAL区: A Multiple-item scale for measuring consumer perceptions of service quality. Journal of Retailing, vol. 64, no. 1 spring, pp. 12-40.

[29] Popoola, N. (2013). The effect of trust in adoption of Internet banking: A case study of Nigeria. International Journal of Economic and Business Management, vol. 1, no. 2, pp. 19-24. Retrieved from http://www.academicresearchjournals.org/JJEBM/ PDF2013/November/POPOOLA.pdf

[30] Riel, C. B. M. and F. C. J. (2007). Essential of Corporate Communication. Implementing practices for effective reputation managemen. New York: Taylor \& Francis Group. 
[31] Rust, R. T. and Oliver, R. L. (1994). Service quality: Insights and managerial implications from the frontier, in R. T. Rust and R. L. Oliver (eds.) Service Quality: New Directions in Theory and Practice, pp. 1-19. California: SAGE Publishing.

[32] Savaneviciene, A. and Stankeviciute, Z. (2010). The models exploring the "Black Box" between HRM and organizational performance. Engineering Economics, vol. 21, no. 4, pp. 426-434. Retrieved from https://doi.org/10.5755/j01.ee.21.4.11719

[33] Savaneviciene, A. and Stankeviciute, Z. (2012). Human Resource Management and Performance: From Practices Towards Sustainable Competitive Advantage (2009).

[34] Serdar Dinç, I. (2000). Bank reputation, bank commitment, and the effects of competition in credit markets. Review of Financial Studies, vol. 13, no. 3, pp. 781812.

[35] Shamma, H. M. (2012). Toward a comprehensive understanding of corporate reputation: Concept, measure and implications. International Journal of Business and Management, vol. 7, no. 16, pp. 151-169.

[36] Theis, R. (2016). Perbandingan Kinerja Keuangan Bank Umum Pemerintah Dan Bank Swasta Nasional (Devisa) Yang Go Publik Di BEl (Periode 2010-2014). Jurnal Berkala Ilmiah Efisiensi, vol. 16, no. 01, pp. 914-924.

[37] Tolbize, A. (2008). Generational differences in the workplace. Research and Training Center on Community Liviing, vol. 4, no. 3, pp. 1-8.

[38] Prasentiantono, T. (2017). A Tony Prasentianono-Konsolidasi Bank BUMN Apa Perlunya. Gatra 17 Mei, pp. 72-73.

[39] Topalian, A. (1984). Corporate identity: Beyond the visual overstatements. International Journal of Advertising, vol. 3, Pp. 55-62.

[40] Weick, K. E. (1979). The Social Psychology of Organizing (Addison-Wesley, ed.). Administrative Science Quarterly, vol. 2. Addison-Wesley. Retrieved from https: //doi.org/10.2307/2392295

[41] Wright. S. (1960). Path coefficients and path regressions - Alternative or complementary concepts. Biometrics, vol. 16, no. 2, pp. 189-202. 